\title{
A SURVEY OF STUDENTS' LANGUAGE LEARNING STRATEGIES AND THEIR ENGLISH LEARNING ACHIEVEMENT IN SMA NEGERI 1 PALOPO
}

\section{Muhammad Iksan and Duriani \\ STIE Muhammadiyah Palopo}

\begin{abstract}
The objectives of this research were: (1) To investigate the dominant language learning strategies (LLSs) used by the students in SMA Negeri 1 Palopo; (2) To investigate the dominant LLSs used by the high and low achiever students in SMA Negeri 1 Palopo; and (3) To investigate the correlation between the students' dominant LLSs and their English achievement.

This research involved 63 students that were chosen using cluster random sampling technique. The data that was obtained through SILL questionnaire and English achievement test were analyzed using descriptive statistics through SPSS software version 21.0.

The findings revealed that the students use all of the six categories of LLSs given by Oxford (1990), and the most dominant used LLSs category by the students are metacognitive strategies $(39.76 \%)$, followed by affective strategies $(16.95 \%)$, while the least dominant used strategies by the students are social strategies (7.60\%), followed by memory strategies (8.77\%). The high achiever students dominantly use cognitive strategies (40\%), followed by metacognitive strategies (30\%), while the low achiever students dominantly use metacognitive strategies $(42.22 \%)$, followed by affective strategies (16.67\%). The Chi-square analysis reveals that accumulatively, there is no statistical correlation between the dominant categories of LLSs that the students use with their English achievement.
\end{abstract}

Keywords: Language learning strategies, English Achievement. 


\section{Introduction}

In learning second language, learners are influenced by several factors. Ellis (1997:73) mentioned social and also some psychological factors have an important role in determining the success of an individual in second language (L2) acquisition. In psychological dimension, she mentioned several factors such as personalities, learning styles, language aptitude, motivation and also differences in learning strategies as factors that strongly affect the learner's development in learning and using second language (L2).

Oxford (1990:1) mentioned that strategies are very necessary to support language learning in order to encourage the learners to be active and to get themselves to be directed involved in their learning process, in which those two aspects are very important in developing communicative competence. Language learning strategies (LLS) itself are defined variously by experts, one most popular definition used is given by Oxford (1990). Oxford (1990:8) defined language learning strategies as "specific actions that learners choose in order to make their learning to be easier, faster, enjoyable, more self-directed, more effective, and more transferrable to new situations".

At school, language learning strategies are generally not included in the curriculum as one of the materials that students have to learn in the classroom and very rarely the English teachers try to explain these to their students. As the result, the understanding of students about what Language Learning Strategies is, what the categories are, and which one that they occupy or better to occupy is very low. Even the students who have a high score in English subject, they never know what kind of strategy that they occupy in order to help them to learn English better than others.

Some of students in Palopo can learn English very well and get a very good achievement in their English subject. Being asked about their success in learning English, several of them said that they learn it from courses, while the others said that they learn it by themselves through an autodidact learning, some also said they learn it from their family, their brothers, sisters or their parents who are also English students or English Teachers.

However, on the other hand, some facts show a very contradictive situation. In two colleges, STAIN Palopo and Cokroaminoto University, that conduct English education study program, several problems sometimes raised for English Students. It is frequently found that several students of English Education Study Program decided to stop their study or move to other colleges for other department or just move to other department and still in the same 
college. Another case is that it is still frequently found students who are in the third and the fourth year of their study, yet they are still very low in terms of English skills.

Students also have various reasons for why they found those kinds of troubles in their learning. Some of them said that they don't have enough exposure to the language, English. The other said that they are not very talented in it, and some other also said that they have tried to learn it harder but they still found it difficult and couldn't get quite succeed in their learning.

In Senior High School (SMA), the students is in around the final phase of adolescent age. According to Jean Piaget (2005:122), individual whose age from 11-12 years and during adolescence, has acquired perfect formal thought and its groupings characterize the completion of reflective intelligence. SMA is the level of education where the students are cognitively considered starting to be mature to conciously manage their learning. In this level of education as well, they get more chance, time and exposure to English, beside in Junior High School (SMP) and Elementary School (SD). Therefore, this level is considered to be the critical stage where the students can conciously enhance and boost their English language learning before coming to the university where the role of their English competence are starting to be demanded either formally or non-formally.

Regarding to the descriptions above, the researcher is interested to conduct a research at senior high school Number 1 Palopo, one of the institution where the students get more time to learn English before come to colleges, to investigate about the language learning strategies that students use. The researcher will also try to find out the correlation of the strategies they use with their English achievement.

\section{Research Methodology}

This research employed correlational research method. Correlational research is research that involves the collection of data in order to determine the whether there is a relationship or not and also the degree of the relationship between two or more quantifiable variables (Gay et al.: 2006). This research analized the relationship between the students' language learning strategies and their English achievement. It also presented a brief descriptions of the language learning strategies and the English achievement of the students in SMA Negeri 1 Palopo.

The population of this research were the students of SMA Negeri 1 Palopo from grade 1 to grade 3 . The total number of the population is 943 students from whole levels. 
The sample of this research were taken using cluster random sampling technique. The sample of the research were taken from all grades. The researcher randomly chose six classes from the three levels, two classes from the first grade, two classes from the second grade and two classes from the third grade that consist of 1 class from IPA and one class from IPS from each level. As the result, there were 171 students from six classes as the sample cluster of the research.

In collecting the data, the writer used two kinds of instruments, they are: (1) Adapted Strategy Inventory For Language Learning (SILL) version 7.0; and (2) English achievement test. SILL is a standardized questionnaire that is designed by Oxford (1989) in Oxford (1990:293) and becomes the most popular used questionnaire in studies conducted to investigate the language learning strategies used by the learner. The SILL questionnaire itself consist of 50 items of statements and are subcategorized into six parts that represent the subcategories of language learning strategies that are given by Oxford (1990). Each part of the questionnaire contains various number of items, where the Part A contains 9 items, Part B contains 14 items, Part C contains 6 items, Part D contains 9 items, Part E contains 6 items, and Part F also contains 6 items. The SILL questionnaire is originally made in English, yet, considering the effectiveness of the questionnaire to reflect the students' strategy, it was translated into Bahasa Indonesia in order that they could easily understand and give respond to the questionnaire.

While English Achievement test is a test that is intended to show the standard which the students have now reached in relation to other students at the same stage (Harrison, 1983:7). This test is developed by the writer based on the syllabus that is used in the schools that are taken as the subject of the research. The whole contents of the test were taken from the material that the students should have learned in the first semester. It consists of 40 items of questions that covers four aspects of language, they were listening skill, reading skill, grammar and vocabulary. The listening skill question consists of 10 items, reading skill questions consists of 10 items, grammar question consists of 10 questions, and vocabulary question consists of 10 items.

The analysis of the data that was gained from the two questionnaires was done in three phases. The first data to analyze was the data from the SILL questionnaire, secondly was the data from the achievement test, and lastly was the correlational analysis between the language learning strategies that the students use and their English achievement using chi-square technique and assisted by Statistical Pack for Social Sciences (SPSS) version 21. 
The correlational analysis were intended to answer the hypothesis as follows: (H0) The students' English achievement doesn't correlate to their dominant language learning strategies; (H1) The students' English achievement correlates to their dominant language learning strategies.

\section{Findings}

\section{The LLSs that students use}

The data about the students' language learning strategies were gained by using the adapted SILL (Strategy Inventory for Language Learning) version 7.0 for speakers of other languages learning English given by Oxford (1990). There are 171 students of SMA Negeri 1 Palopo as the samples of the research.

From the SILL questionnaire, it is found that the students of SMA Negeri 1 Palopo used all the categories of LLSs given by Oxford (1990) i.e. memory strategies; cognitive strategies; compensation strategies; metacognitive strategies; affective strategies; and social strategies.

However, although all the categories of LLSs were used by the students, the levels of the LLSs use of each students are various. Table 4.1 shows the frequency of the level of LLSs use of the students.

Table 4.1: Frequencies, means and standard deviations of the level of LLSs use

\begin{tabular}{|l|r|r|r|}
\hline \multicolumn{1}{|c|}{ Level } & \multicolumn{1}{c|}{ N } & \multicolumn{1}{c|}{ Mean } & \multicolumn{1}{c|}{ Std. Deviation } \\
\hline High & 16 & 3.725 & .2145 \\
\hline Medium & 114 & 2.942 & .2828 \\
\hline Low & 41 & 2.176 & .2596 \\
\hline Valid N (listwise) & 16 & & \\
\hline
\end{tabular}

The table shows that there are 16 students who are categorized to be high (usually, almost always and always) users of LLSs, while 114 students are categorized to be medium (sometimes) users, and 41 students are categorized as low users. The table also shows that the highest mean among the three levels of LLSs use is the mean of the high level of LLSs use (almost always always use) by mean 3.725 . The findings in the table above indicates that by frequencies, the 
students of SMA Negeri 1 Palopo are categorized as medium users of LLSs although the means score shows that the high LLSs users had the highest mean score (3.725).

Furthermore, the description of the use of LLSs by the students of SMA Negeri 1 Palopo that was found from SILL questionnaire can be seen in table 4.2 below:

Table 4.2: Frequencies and means of Students' LLSs

\begin{tabular}{|l|r|r|r|}
\hline \multicolumn{1}{|c|}{ LLSs } & N & Mean & $\begin{array}{c}\text { Std. } \\
\text { Deviation }\end{array}$ \\
\hline Memory & 15 & 2.880 & .3468 \\
\hline Cognitive & 19 & 2.879 & .6877 \\
\hline Compensation & 27 & 2.764 & .5637 \\
\hline Metacognitive & 68 & 2.872 & .4809 \\
\hline Affective & 29 & 2.676 & .4673 \\
\hline Social & 13 & 2.985 & .4758 \\
\hline \multicolumn{2}{|c|}{ Valid N (listwise) } & \multicolumn{2}{|c|}{13} \\
\hline
\end{tabular}

From the table above the LLSs use of the students in SMA Negeri 1 Palopo can be mentioned in general as follows:

1) The most dominant used strategies by the students is metacognitive strategies (68 students), followed by affective strategies (29 students).

2) The least dominant used strategies by the students is social strategies (13 students).

3) The highest average of strategies used by the students is Social strategies (mean: 2.985) used by 13 students, and in the second place is memory strategies (mean: 2.880) used by 15 students.

4) The lowest average of strategies used by the students is Affective strategies (mean: 2.676) used by 29 students.

\section{The LLSs of the high and the low achiever students}

The students to be mentioned as high achiever are the students whose English achievement score is 70 above, while the low achiever students are those whose English achievement score is 40 below.From the data that is gained using the English achievement test, there are 10 students whose English achievement test score above 70 or categorized into high achiever, the percentage is about $5.84 \%$ from the total number of the sample. It can be seen in the table below: 
Table 4.3: The LLSs of the high achiever students

\begin{tabular}{|l|l|l|l|}
\hline \multicolumn{1}{|c|}{ NO. } & \multicolumn{1}{c|}{ LLSs } & \multicolumn{1}{c|}{ N } & \multicolumn{1}{c|}{$\%$} \\
\hline 1 & $\begin{array}{l}\text { Cognitive } \\
\text { strategies }\end{array}$ & 4 & 40 \\
\hline 2 & $\begin{array}{l}\text { Compensation } \\
\text { strategies }\end{array}$ & 2 & 20 \\
\hline 3 & $\begin{array}{l}\text { Metacognitive } \\
\text { strategies }\end{array}$ & 3 & 30 \\
\hline 4 & $\begin{array}{l}\text { Social } \\
\text { Strategies }\end{array}$ & 1 & 10 \\
\hline
\end{tabular}

Note: $\mathrm{N}=$ Number/frequency, $\%=$ Percentage

From the table above, it can be seen that there are four dominant categories of LLSs that the high achiever students frequently use, 4 students use cognitive strategies (40\%), 2 students use compensation strategies (20\%), 3 students use metacognitive strategies (30\%), and 1 student uses social strategies (10\%)

The students whose achievement score are below 40 mentioned as low achiever students. From the achievement test, it is found that there are 90 students whose English achievement score below 40. They also use various dominant categories of LLSs. Table 4.4 below shows the dominant categories of LLSs that were used by the low achiever students:

Table 4.4: The LLSs of the low achiever students

\begin{tabular}{|c|l|r|r|}
\hline NO. & \multicolumn{1}{|c|}{ LLSs } & N & \multicolumn{1}{c|}{$\%$} \\
\hline 1 & Memory strategies & 8 & 8.89 \\
\hline 2 & Cognitive strategies & 9 & 10 \\
\hline 3 & Compensation strategies & 11 & 12.22 \\
\hline 4 & Metacognitive strategies & 38 & 42.22 \\
\hline 5 & Affective Strategies & 15 & 16.67 \\
\hline 6 & Social Strategies & 9 & 10 \\
\hline
\end{tabular}


Note: $\mathrm{N}=$ Number/frequency, $\%=$ Percentage

From the table, it can be seen that the low achiever students dominantly use all the categories of LLSs. In which, metacognitive strategies becomes the most dominant used strategies: 38 students (42.22\%), followed by affective strategies: 15 students (16.67\%), compensation strategies: 11 students (12.22\%), cognitive and social strategies: 9 students (10\%) for each, and the last is memory strategies: 8 students $(8.89 \%)$.

\section{The correlation between students' LLSs with their English achievement}

In order to answer the answer the hypothesis questions, Chi square analysis are used to determine whether the dominant categories of LLSs that students use in SMA Negeri 1 Palopo correlate with their English achievement or not.

The result of analysis using IBM SPSS version 21.0, was as seen in the table below:

Table 4.5: LLSs and achievement cross-tabulation

\begin{tabular}{|c|c|c|c|c|c|c|}
\hline & \multicolumn{4}{|c|}{ Achievement } & \multirow[b]{2}{*}{ Total } \\
\hline & & High & Average & Poor & $\begin{array}{l}\text { Very } \\
\text { poor }\end{array}$ & \\
\hline \multirow{6}{*}{ LLSs } & Memory & 0 & 1 & 6 & 8 & 15 \\
\hline & Cognitive & 4 & 3 & 3 & 9 & 19 \\
\hline & Compensation & 2 & 3 & 11 & 11 & 27 \\
\hline & Metacognitive & 3 & 8 & 19 & 38 & 68 \\
\hline & Affective & 0 & 7 & 7 & 15 & 29 \\
\hline & Social & 1 & 1 & 2 & 9 & 13 \\
\hline & Total & 10 & 23 & 48 & 90 & 171 \\
\hline
\end{tabular}

Table 4.6: Chi square tests results

\begin{tabular}{|l|r|r|r|}
\hline & \multicolumn{1}{|c|}{ Value } & \multicolumn{1}{c|}{ df } & \multicolumn{1}{c|}{$\begin{array}{c}\text { Asymp. Sig. } \\
\text { (2-sided) }\end{array}$} \\
\hline Pearson Chi-Square & $20.019^{\mathrm{a}}$ & 15 & .171 \\
\hline Likelihood Ratio & 19.338 & 15 & .199 \\
\hline $\begin{array}{l}\text { Linear-by-Linear } \\
\text { Association }\end{array}$ & .803 & 1 & .370 \\
\hline N of Valid Cases & 171 & & \\
\hline
\end{tabular}

From the table above, it is found that Pearson Chi square was 20.019, and the significance was 0.171 . Furthermore, in order to determine which hypothesis that was accepted, 
there are two ways that could be undergone. The first way is to see the significance. The H0 would be accepted if the significance of the Chi square test is larger than the degree of significance $(\alpha=0.05)$ from the table. From the analysis, it was found that the significance was $0.171>0.05$, therefore, the H0 is accepted that the dominant categories of LLSs that the students use do not correlate with their English achievement.

The second way to determine which hypothesis to be accepted is by comparing the PearsonChi square with the degree of freedom ( $d f)$, by which the $d f$ from the $\mathrm{X}^{2}$ tablewas 15 . Finally, it is found that the Pearson $X^{2}$ (20.019) was lower than the table $X^{2}(24.996)$, therefore it was also concluded that the H0 was accepted.

\section{Discussions}

This part deals with that discussions of the finding with related theories and the findings of some previous related research. The discussions were divided into three parts based on the research questions and the findings.

\section{The Students' dominant LLSs}

This part deals with the level of students' LLSs use and the categories of LLSs that the students dominantly use in their English learning.

a. The level of students' LLSs use

In findings, Table 4.1 shows that by frequency, most of the students of SMA Negeri 1 Palopo are categorized as medium LLSs users where 121 students were found to use LLSs by average 2.5 to 3.4. Besides that, there are 43 students who are categorized as low LLSs users where the students are found to use LLSs by average below 2.4. The least frequency of LLSs users' level are the high LLSs user students where there are only 16 students achieved this level. The categorization is based on what Oxford (292:1990) wrote that the learner whose average score from SILL was 3.5 to 5.0 is categorized as high LLSs user, while the learner whose average score is 2.5 to 3.4 was categorized as medium LLSs user, and the learner whose average score is 1.0 to 2.4 is categorized as low LLSs user. Therefore, by frequency, the students of SMA Negeri 1 Palopo are categorized as Medium LLSs users.

By mean score, the high level LLSs user students have the highest mean score by 3.725 , while the medium LLSs user students have the mean score 2.932, and the low LLSs user students 
have the mean score 2.184. It means that by mean score, the students of SMA Negeri 1 Palopo are categorized as the high LLSs users.

The findings showed that there is a difference between the levels of LLSs use viewed from the frequency and the mean score of the students in SMA Negeri 1 Palopo. It might be related to the argument proposed by the writer in the background of the research before that there is a phenomena in Palopo, where in one hand, there were several of students in SMA Negeri 1 Palopo who were very good in English, while in the other hand, there were lots of them who are considered to be low in English and almost most of them who took English department when they came to colleges decided to quit from the department and move to any other departments.

b. The category of LLSs that the students dominantly use

Table 4.2 in findings shows that by frequency, metacognitive strategies become the most frequent category of LLSs that the students dominantly use where 71 students are found of dominantly using this category, followed by affective strategies where 32 students, while memory and social categories are the lowest frequency of usage LLSs category by 15 students using these strategies.

Based on the findings, the students of SMA Negeri 1 Palopo are categorized to be dominant of using indirect strategies by metacognitive and affective strategies. Because the most dominant strategies used by the students is metacognitive strategies, it means that in learning English, the students of SMA Negeri 1 Palopo tend control their own cognition by coordinating their learning process, such as centering, arranging, planning, and evaluating their learning (Oxford, 136:1990).

Although become the most dominant used by the students, however, the mean score of metacognitive strategies (2.8792) is found to be lower than the mean score of the social (2.9373) and the memory (2.8876) strategies which are found as the highest mean score of all strategies used by the students. It means that though most of the students dominantly use metacognitive and affective strategies, the average and the level of using LLSs of the students who frequently use social and memory strategies were higher. In other words, the students who dominantly use social and memory strategies in their English language learning used LLSs more frequent than the students using another strategies including metacognitive and affective strategies. 
The study conducted by Weda also revealed a rather similar findings. In his study, Weda (2007) found that social and metacognitive became the most popular strategies used by senior secondary school students of SMA Negeri 9 Makassar in learning English. While the least popular strategies used by the students were compensation and cognitive strategies.

\section{The LLSs of the high and low achiever students}

Table 4.3 in findings shows that there are four categories of LLSs that the high achiever students use. Cognitive strategies become the most frequent strategies that dominantly used by 4 students (40\%), and metacognitive was in the second place by 3 students using these strategies $(30 \%)$. The least used strategies by the students is social strategies which only used by 1 student $(10 \%)$.

In table 4.4, it can be seen that the most frequent strategies that dominantly used by the low achiever students are metacognitive strategies: 38 students $(42.22 \%)$ and followed by affective strategies: 15 students $(16.67 \%)$. While the least frequently used strategies are memory strategies: 8 students (8.89\%) followed by cognitive and social strategies: 9 students (10\%) for each.

The findings above reveals that the high achiever students in SMA Negeri 1 Palopo are dominantly used both cognitive strategies and metacognitive strategies. Metacognitive strategies are also found to be the most frequently used strategies by the the low achiever students followed by affective strategies.

The findings are in line with what Oxford (43:1990) mentioned that cognitive strategies is one of the most popular LLSs used by the language learners. Oxford (136:1990) also mentioned that metacognitive strategies play a very important role in the success of a language learner.

The findings of the study is also in line with the result of the study conducted by Said (2013). In her study, Said (2013) found that metacognitive and Cognitive strategies became the most frequently used by the high achiever students of the sixth semester students of English Education Department in STAIN Palopo, while affective and compensation strategies were found to be the most frequently used by the low achiever students. 


\section{The correlation between the students' dominant LLSs with their English achievement}

From the findings, it is found that the $\mathrm{H} 0$ is accepted where the significance of the Chisquare test is larger than 0.05, and the value of the Chi-square test (20.019) is lower than the Chisquare from the table (24.996). It means that the dominant categories of LLSs that the students use do not correlate with their English achievement. Hence, it could not be assumed that a certain category of LLSs in only used by students with certain level of English achievement.

The finding is in line with the result of the study conducted by Shabankareh et al. (2011). From their comparative study about the language learning strategies between the high-level and low-level learners learning English as a foreign language in Iran, Shabankareh et al (2011) found that there is no meaningful difference is seen between the categories.

In the other hand, the finding is partly on the contrary with the result of the study conducted by Jhaish (2010). In his study, Jhaish found that there were statistically significant correlation coefficient between achievement and all strategies except the compensation strategies.

This result reflects the arguments of Ellis (1997) that there are numbers of factors that influence the learners in learning second language, such as personalities, learning styles, language aptitude, motivation and also differences in learning strategies as factors that strongly affect the learner's development in learning and using L2. It was mentioned by Ellis that differences in learning strategies are only a piece of factors that affect the success of students in learning English.

In previous part, it is also found that the level of LLSs use of the students in SMA Negeri 1 Palopo is on medium level, it means that the students' use LLSs in their English learning is not very frequently. It is true that in this case, another factors including the individual differences factors might play significant role in affecting the students' achievement besides LLSs.

\section{Conclusions}

Based on the findings and discussions in the previous chapter, the result of this study is concluded as follows:

1. The students are found to be medium users of LLSs by overall average of LLSs use $2.5-$ 3.4. Of all the six categories of LLSs, the students used all the categories of LLSs. By which the most dominant used category was metacognitive strategies by 68 students $(39.76 \%)$, followed by affective strategies by 29 students (16.95\%). While the least dominant used 
category was social strategies by 13 students (7.60\%), followed by memory strategies by 15 students $(8.77 \%)$.

2. Cognitive strategies is the most dominant used category by 4 high achiever students (40\%), followed by metacognitive strategies by 3 students (30\%), compensation strategies by 2 students (20\%), and social strategies by 1 student $(10 \%)$. While metacognitive strategies becomes the most dominant used category by the low achiever students by 38 students (42.22\%), followed by affective strategies by 15 students (16.67\%), compensation strategies by 11 students (12.22\%), cognitive and social strategies by 9 students (10\%), and memory strategies by 8 students $(8.89 \%)$.

3. Accumulatively, there is no statistical correlation between the dominant categories of LLSs that the students use with their English achievement. Therefore, it could not be assumed that a certain LLSs category is only used by students with certain achievement level in SMA Negeri 1 Palopo.

\section{Suggestions}

Based on the conclusions above, the researcher presents some suggestions and recommendations as follows:

1. Further investigations are needed dealing with the students' dominant LLSs categories and their correlation with their English achievement in order to establish a better paradigm and a comprehensive understanding of the role of LLSs in determining the students' success in learning English. Strategies training might be necessary before investigating the students' dominant LLSs and their correlation with their English achievement.

2. Language learning strategies are essential in influencing the success of students in learning English. Therefore, it is suggested to the students to learn and try to apply language learning strategies (LLSs) in their learning process.

3. Cognitive strategies are dominantly used by the high achiever students, therefore, it is recommended to the students to learn and apply cognitive strategies in order to help improving their English learning.

4. It is recommended to teachers to investigate the LLSs that their students tend to use by then they can adjust their teaching methodology and the material that they present to their students to meet the students' tendency in learning English.

5. It is also recommended to teachers that they can comprehend and introduce the categories of LLSs and provide time to train their students of applying the LLSs in learning English. 
6. The government, especially the department of education is suggested to allocate time and fund for programs to introduce LLSs to teachers and students, and to train LLSs to students in order that they can comprehend and apply LLSs in order to help improving their English learning.

\section{Bibliography}

Abbas, A. 2013. An Investigation of Students' Language Learning Strategies in Mastering Speaking Skill at English and Literature Department of UIN Alauddin Makassar. Unpublished Thesis. Makassar: PPs. UNM.

Aminah, St. 2013. A Study of Motivation and Attitudes and Their Correlation With English Learning Achievement of the First Year Students of SMA Negeri 2 Pangkajene. Unpublished Thesis: Makassar. PPs. UNM.

Arikunto Suharsini. 2006. Prosedur Penelitian: Suatu Pendekatan Praktek. Jakarta: Rineka Cipta

Brown, H. D. 1994. Teaching by Principles an Interactive Approach to Language Pedagogy. Englewood Cliffs, Prentice Hall Regents.

Chen, M. \& Hung, L. 2012. Personality Type, Perceptual Style Preferences, and Strategies for Learning English as a Foreign Language. Social Behavior and Personality, (online), Vol. 40 No. 9 (www.sbp-journal.com/index.php/sbp/article/view/2573, accessed on February $\left.15^{\text {th }} 2014\right)$

Cook, V. 1991. Second Language Learning and Teaching. London: Edward Arnold.

Dörnyei,Zoltán. 2005. The Psychology of the Language Learner: Individual Differences in Second Language Acquisition. London: Lawrence Erlbaum Associates, Inc., Publishers

Dulay, H., Burt, M. \& Khrasen, S. 1982. Language Two. New York: Oxford University Press.

Ellis, R. 1997. Second Language Acquisition. Oxford: Oxford University Press.

Fazeli, S. H. 2012. The Relationship between the Extraversion Trait and Use of the English Language Learning Strategies. Indian Journal of Science and Technology, (online) Vol. 5 No. 4 (http://www.indjst.org/index.php/indjst/srticle/viewFile/30439, accessed on February $15^{\text {th }} 2014$ )

Fazeli, S. H. 2012. The Role of Personality Traits in the Choice and Use of the Compensation Category of English Language Learning Strategies. Indian Jou.rnal of Science and 
Technology, (online), Vol. 5 No. 6 (http://www.indjst.org Indian J.Sci.Technol., accessed on February $15^{\text {th }}$ 2014)

Fazeli, S. H. 2012. The Influence of Personality Traits on the use of Memory English Language Learning Strategies. Indian Journal of Science and Technology, (online) Vol. 5 No. 7 (http://www.indjst.org/index.php/indjst/srticle/viewFile/30509, accessed on February $15^{\text {th }}$ 2014).

Gage, N. L. \& Berliner, D. C. 1992. Educational Psychology. $5^{\text {th }}$ Edition. Boston: Houghton Mifflin Company.

Harrison, A. 1983. A Language Testing Handbook. London: Macmillan Publishers.

Krashen, S. D. 1981. Second Language Acquisition and Second Language Learning (Internet Edition: 2002). Oxford: Pergamon Press.

Jhaish, M. A. 2010. The Relationship among Learning Styles, Language Learning Strategies, and the Academic Achievement among the English Majors at Al-Aqsa University. Unpublished Thesis.. Gaza, Palestine: The Islamic University of Gaza. (online accessed on 10 February 2014)

Krashen, S. D. 1982. Principles and Practice in Second Language Acquisition (Internet Edition: 2009). Oxford: Pergamon Press.

Little, D. 2001. Learning English as a Second Language: Acquisition and Instruction (Online), www.ncca.ie/uploadedfiles/Curriculum/inclusion/ESL_primary.pdf., accessed on $28^{\text {th }}$ of February 2014)

Nurlailah. 2012. Effective Learning Strategies Applied by the English Learners in Al Markaz for Khudi Enlightening Studies (MAKES). Unpublished Thesis. Makassar: PPs. UNM.

O’Malley, J. M., \& Chamot, A. U. 1990. Learning Strategies in Second Language Acquisition. New York: Cambridge University Press.

Oxford, R. L. (1990). Language Learning Strategies: What Every Teacher Should Know. New York: Newbury House.

Piaget, J. 2005. The Psichology of Intelligence. Internet E-book Edition. London: Taylor \& Francis E-Library.

Purwanto, M. N. 2010. Psikologi Pendidikan. Bandung: PT. Remaja Rosdakarya

Ramirez, A.G. 1986. Language Learning Strategies used by Adolescents Studying French iin New York Schools. Foreign Language Annuals, Vol. 19. No. 2 (131-141). 
Rowe, C. \& Fry, J. Memory Strategies (Online), (http://faculty.mercer.edu/spears a/studentpages/memory strategies/html3.htm., accessed on on 06 March 2014).

Rubin, J. 1975. What the "Good Language Learner” Can Teach us. TESOL Quarterly, 9, (4151).

Said, Y. R. 2013. Learning Strategies Used by the Students of English Department of Tarbiyah Faculty at STAIN Palopo. Unpublished Thesis. Makassar: PPs. UNM.

Sardiman, A. M. 2012. Interaksi dan Motivasi Belajar Mengajar. Jakarta: PT. Raja Grafindo Persada.

Saville, M. \& Troike. 2006. Introducing Second Language Acquisition. New York: Cambridge University Press.

Setiyadi, A. B. 2006. Teaching English as a Foreign Language. Yogyakarta: Graha Ilmu.

Shabankareh N. N .T. \& Hadizadeh A. 2011. A Comparison of Language Learning Strategies (LLSS) between Bilingual and Monolingual Learners, Female and Male Learners, High School and University Students, and High-Level and Low-Level Learners Learning English as a Foreign Language in Iran. International Journal of Arts \& Sciences, 4(8):122 (CD-ROM).

Skehan, P. 1989. Individual Differences in Second Language Learning. London: Edward Arnold

Soeprapto F.A., Darwis, M. 2006. Linked to the World 2 - English for Senior High School Grade $X I$. Jakarta: Yudhistira.

Sujarweni, V. W. 2014. SPSS untuk penelitian. First Edition. Yogyakarta: Pustaka Baru Press.

Sukmadinata, N.S. 2007. Landasan Psikologi Proses Pendidikan. Fourth Edition. Bandung: Remaja Rosdakarya.

Leo, S., Groth, C., Kendra, I. L., Lilyana, S., Lukman, E. A., Yugianingrum. 2013. English for Academic Purposes: Essay Writing. Second Edition. Yogyakarta: Penerbit Andi.

VanPatten,B. \&Benati, A. G. 2010.Key Terms in Second Language Acquisition. London: Continuum International Publishing Group.

Weda, S. 2007. English Learning Strategies. Makassar: Lembaga Pusat Pengembangan Masyarakat Marginal (LPPMM).

Winkel, W. S. 1983. Psikologi Pendidikan dan Evaluasi Belajar. Jakarta: Gramedia. 